\title{
Parasitological survey on birds at some selected brazilian zoos
}

\author{
Levantamento parasitológico em aves de alguns zoológicos brasileiros \\ Paulo Gonzalez Hofstatter ${ }^{1 *}$; Ana Maria Aparecida Guaraldo ${ }^{1}$
}

${ }^{1}$ Department of Animal Biology, Institute of Biology, Universidade Estadual de Campinas - UNICAMP, Campinas, SP, Brazil

Received November 4, 2014

Accepted December 8, 2014

\begin{abstract}
A parasitological survey was conducted at some zoos in the states of São Paulo and Paraná, Brazil, from 2009 to 2011. Several groups of birds were surveyed for fecal samples, but the most important was Psittacidae. Among the parasites, Eimeria (coccidian) and Capillaria, Ascaridia and Heterakis (nematodes) were observed in almost one third of the samples. Presence of a rich parasite fauna associated with captive birds seems to be an effect of captivity, since data on free-ranging birds indicate few or virtually no parasites at all. The discovery of new coccidian species during this survey reveals the need of more research on the subject as even well-known bird species have unknown parasites, but caution must be exercised in order to avoid descriptions of pseudoparasites.
\end{abstract}

Keywords: Ascaridia, Capillaria, Cracidae, Eimeria, Psittacidae.

\section{Resumo}

Um levantamento parasitológico foi conduzido em alguns zoológicos dos Estados de São Paulo e Paraná, Brasil, de 2009 a 2011. Vários grupos de aves foram examinados por meio de amostras fecais, sendo o mais importante o Psittacidae. Entre os parasitas, Eimeria (coccidio) e Capillaria, Ascaridia e Heterakis (nematoides) foram observados em quase um terço das amostras. A presença de uma rica fauna parasitária associada a aves cativas parece ser um efeito do cativeiro, já que dados oriundos de animais de vida livre mostraram poucos ou virtualmente nenhum parasita. A descoberta de novas espécies de coccídeos durante esse levantamento revela a necessidade de mais pesquisas sobre o assunto, pois até espécies de aves bem conhecidas têm parasitas desconhecidos, por isso toda cautela é necessária para se evitar a descrição de pseudoparasitas.

Palavras-chave: Ascaridia, Capillaria, Cracidae, Eimeria, Psittacidae.

\section{Introduction}

Most of the birds kept at zoos in Brazil belong to native species. Among these, psittacine species are the most common and diverse, but Cracidae, Ramphastidae, Passeriformes and ratites are also present. Little is known about their parasites and deaths are fairly common in captivity, some probably due to high parasite loads. For instance, the infection with Sarcocystis falcatula may lead psittacids to acute fatal disease (CLUBB \& FRENKEL, 1992).

The most common gut parasites of birds are nematodes (mainly ascarids and capillariids) and protozoa (usually coccidians). In a survey conducted by Cordón et al. (2009) on birds (mostly psittacids) at the Almuñecar ornithological garden in Spain, roughly half of the samples were positive for some type of parasite. Capillaria sp. was the most prevalent nematode, but Ascaridia sp. and Heterakis sp. were found as well. Among protozoa, the most prevalent were Blastocystis sp. and coccidians (mostly Eimeria sp. and unidentified oocysts). Hemoparasites were

${ }^{*}$ Corresponding author: Paulo Gonzalez Hofstatter, Department of Animal Biology, Institute of Biology, Universidade Estadual de Campinas - UNICAMP, Rua Monteiro Lobato, 255, CP 6109, CEP 13083-862, Campinas, SP, Brazil, e-mail: paullogh@hotmail.com also found, namely Plasmodium and Haemoproteus. Patel et al. (2000) also found parasite prevalence of $50 \%$ among birds at the Gujarat zoo, India, and the most common parasitic genera were Capillaria, Ascaridia and Eimeria.

In Brazil, Freitas et al. (2002) found overall prevalence of 46.7\% among Psittacidae, Cracidae, Phasianidae, Columbidae and other avian groups in captivity. The most common parasitic genera were again Capillaria and Ascaridia, along with Strongyloides, 'coccidians' and others.

The aim of this study was to obtain data on prevalence and diversity of intestinal parasites from fecal samples of captive birds, mostly psittacids, kept in some selected Brazilian zoos.

\section{Materials and Methods}

Fecal samples $(\mathrm{n}=170)$ from individuals or pairs of the same species were collected by fresh deposit on cage floor or dry paper, when possible, from 2009 to 2010 from several species of birds kept at some Brazilian zoos. These species were mostly Psittacidae 
(85.3\% of the samples) along with Cracidae (4.1\%), Cacatuidae (1.8\%) and others (8.8\%): Cathartidae, Ramphastidae, Psophidae, Strutioniformes, Icteridae and Musophagidae. The samples were stored in $2.5 \%$ potassium dichromate solution $\left(\mathrm{K}_{2} \mathrm{Cr}_{2} \mathrm{O}_{7}\right)$. These samples were obtained from zoos in Americana, Bosque dos Jequitibás (Campinas), Itatiba and Guarulhos, which are all in the state of São Paulo; and from the Bird Park of Foz do Iguaçu, Paraná.

In the laboratory, the fecal material was filtered through a $154 \mu \mathrm{m}$ sieve using clean water and was concentrated by means of centrifugation at 1,200 $\mathrm{g}$ for $5 \mathrm{~min}$. Nematode eggs and coccidian oocysts were obtained by flotation in sucrose solution ( $\mathrm{d}=1.2 \mathrm{~g} / \mathrm{mL}$ ) using the Sheather method (SHEATHER, 1923). Unsporulated oocysts obtained in this way were allowed to sporulate on a dish containing $2.5 \%$ potassium dichromate solution at room temperature for a few days.

The oocysts and nematode eggs were photographed under a Zeiss ${ }^{\oplus}$ light photomicroscope and then measured using the Image Manager IM50@ software (Leica IM50 4.0 Imagic Bildverarbeitung AG; Leica Microsystems Imaging Solutions Ltd., Cambridge, U.K.).

\section{Ethics}

Although not involving animal experimentation, all procedures performed through this project were subject to and approved by our Institution's Ethics Committee for Animal Use (CEUA, UNICAMP) under number 1923-1.

\section{Results}

Despite low prevalence of coccidians (3.5\%), nematodes were present in every zoo surveyed, with prevalence of $26.5 \%$. The overall prevalence of samples testing positive for nematode eggs or coccidian oocysts was $29.4 \%$ (50 out of 170 ).

\section{Coccidia}

Coccidians, mostly Eimeria, were infrequently observed (6 out of 170 samples), although present in samples from Psittacidae, Cracidae and Ramphastidae. Some new eimerian species were described as part of this project: E. abmitu (Figure 1), host: Mitu tuberosum (HOFSTATTER \& GUARALDO, 2011a) and
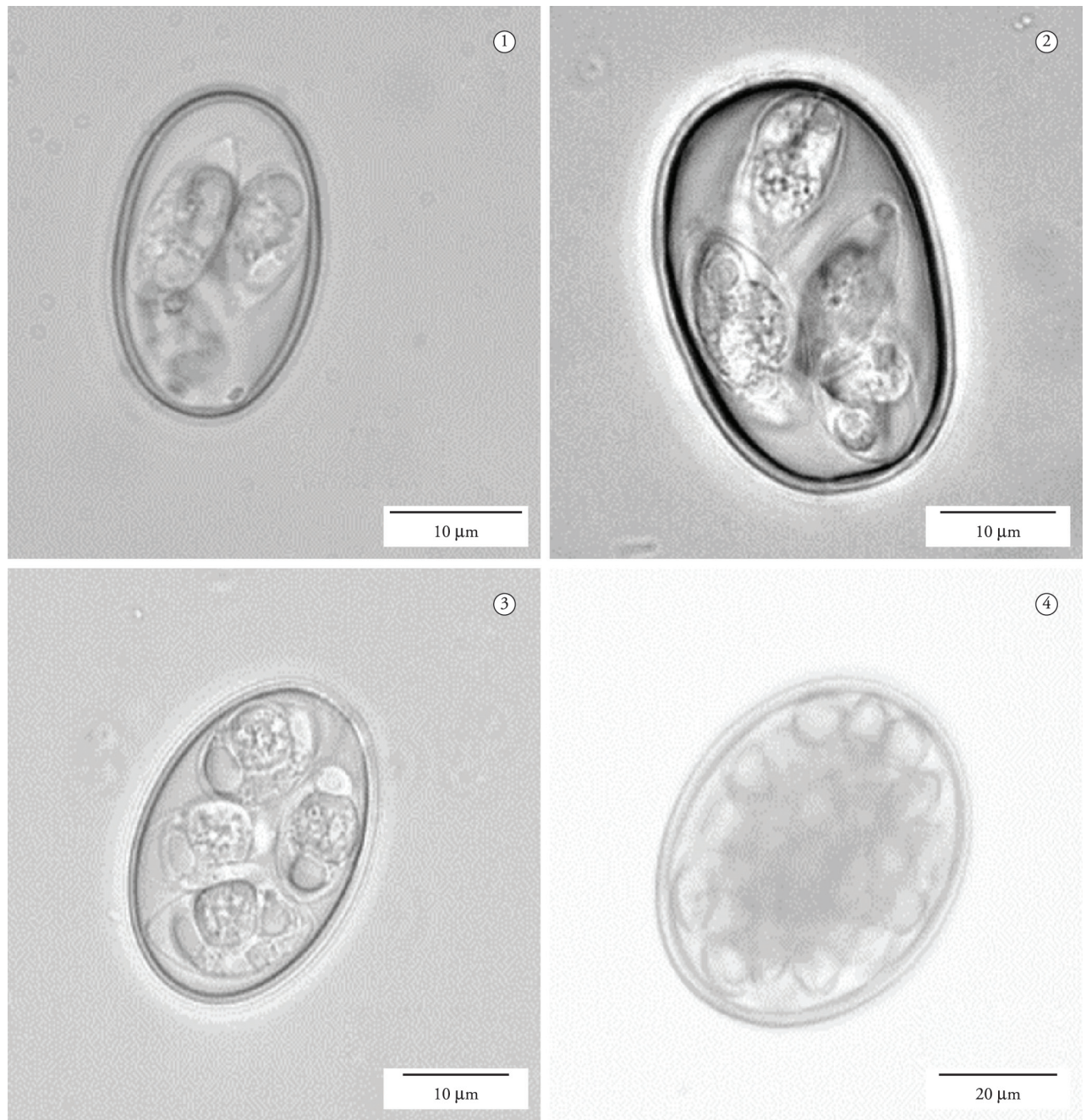

Figures 1-4. 1. Eimeria abmitu from Mitu tuberosum; 2. Eimeria aestivae from Amazona aestiva; 3. Eimeria forresteri from Ramphastos toco; 4. Unidentified polysporocystic oocyst from Cacatua alba, probably an adeleid pseudoparasite from insects. 
E. amazonae (Figure 2), host: Amazona aestiva (HOFSTATTER \& GUARALDO, 2011b).

Eimeria forresteri (UPTON et al., 1984) (Figure 3) was identified in samples from Ramphastos toco. An unidentified poly-sporocystic coccidian was observed in Cacatua alba (Figure 4), probably a pseudoparasite from insects.

\section{Nematodes}

Nematodes were much more frequent than protozoa (45 out of 170 samples). Among these, Capillaria sp. (or Ornithocapillaria sp.) was the most abundant in psittacid samples. Its presence was confirmed in every zoo. Capillaria plagiaticia (FREITAS et al., 1959) was obtained from the gut of a dead Hyacinth Macaw individual. Furthermore, Ascaridia sp., Heterakis sp. and an unidentified nematode were also present in samples from psittacids. Unidentified nematode eggs were also observed in samples from ostriches (Struthio camelus) (Table 1).

\section{Discussion}

In our study, almost one-third of the samples were positive for at least one parasite. This result was similar to the findings from other surveys in zoos, and this prevalence was higher than among free-ranging birds. The results of Freitas et al. (2002) regarding captive psittacids in northeastern Brazil were very similar to ours, thus indicating that the same parasitic agents are associated with Brazilian psittacids all over the country and elsewhere too, since data from studies in other countries also bear similarities to ours (CORDÓN et al., 2009; PATEL et al., 2000). Thus, the most important parasites of parrots in captivity are nematodes of the genera Capillaria and Ascaridia.

Authors working with free-ranging birds have failed to detect any intestinal parasites associated with psittacine birds (GILARDI et al., 1995; STONE et al., 2005; MASELLO et al., 2006; ALLGAYER et al., 2009). In contrast, the data obtained from birds in zoos show high prevalence of parasites (PATEL et al., 2000; CORDÓN et al., 2009), thus indicating that captivity may facilitate transmission between individuals and also raise the parasitic load in the hosts. There seems to be a trend for captive birds to have bigger loads of associated parasitic fauna than those of free-ranging birds.

It seems that high prevalence and heavy parasitic load are not natural among those birds, which may threaten the health of birds held in captivity and even cause deaths, either due to the parasites themselves or due to secondary infections derived from their presence. Several suspicious deaths of individuals occurred in these zoos before and during this study, which may be attributed to complications caused by heavy parasite loads. Reasonable knowledge of the associated parasite fauna would enable more efficient disease control, in order to prevent the loss of specimens through easily avoidable causes. Clubb \& Frenkel (1992) have controlled outbreaks of fatal Sarcocystis infection in psittacine birds by cockroach control in and around the facility where the birds were held.

The description of new coccidian species during this survey reveals the need of more research on the subject as even well-known bird species have unknown parasites. Most surveys are superficial in identification of parasites and it seems to be the case, several new species are frequently overlooked as in Freitas et al. (2002), Patel et al. (2000) and Cordón et al. (2009). But we need to exercise caution in order to avoid erroneous descriptions

Table 1. Nematodes, their hosts and zoos surveyed from 2009 to 2010 in the State São Paulo and Paraná, Brazil.

\begin{tabular}{|c|c|c|}
\hline Nematodes & Hosts & Zoos \\
\hline \multirow{14}{*}{$\begin{array}{l}\text { Capillaria sp. } \\
\text { (Figure 5) }\end{array}$} & Ara ararauna, $A$. macao & \multirow[t]{2}{*}{ Bosque dos Jequitibás } \\
\hline & Amazona aestiva, $A$. amazonica & \\
\hline & Amazona aestiva & \multirow[t]{4}{*}{ Zoológico de Americana } \\
\hline & Anodorhynchus hyacinthinus & \\
\hline & Ara ararauna, $A$. rubrogenis, & \\
\hline & Ara macao & \\
\hline & Ara chloropterus, Ara macao, & \multirow[t]{5}{*}{ Zooparque de Itatiba } \\
\hline & Ara ararauna & \\
\hline & Amazona aestiva, A. brasiliensis, & \\
\hline & A. farinosa, A. ochrocephala & \\
\hline & Pionus menstruus & \\
\hline & Amazona vinacea & \multirow[t]{2}{*}{ Parque das Aves (Bird Park) Foz do Iguaçu } \\
\hline & Pionus maximiliani & \\
\hline & Ara macao & Zoológico de Guarulhos \\
\hline Ascaridia sp. & Amazona amazonica & Bosque Jequitibás \\
\hline (Figure 6) & Amazona aestiva, A. ochrocephala & Zooparque Itatiba \\
\hline $\begin{array}{l}\text { Heterakis sp. } \\
\text { (Figure } 7 \text { ) }\end{array}$ & $\begin{array}{l}\text { Amazona aestiva, A. farinosa, } \\
\text { A. ochrocephala }\end{array}$ & Zooparque de Itatiba \\
\hline Unidentified psittacid nematode (Figure 8) & Amazona aestiva & Zooparque de Itatiba \\
\hline Unidentified ostrich nematode & Struthio camelus & Zooparque de Itatiba \\
\hline
\end{tabular}



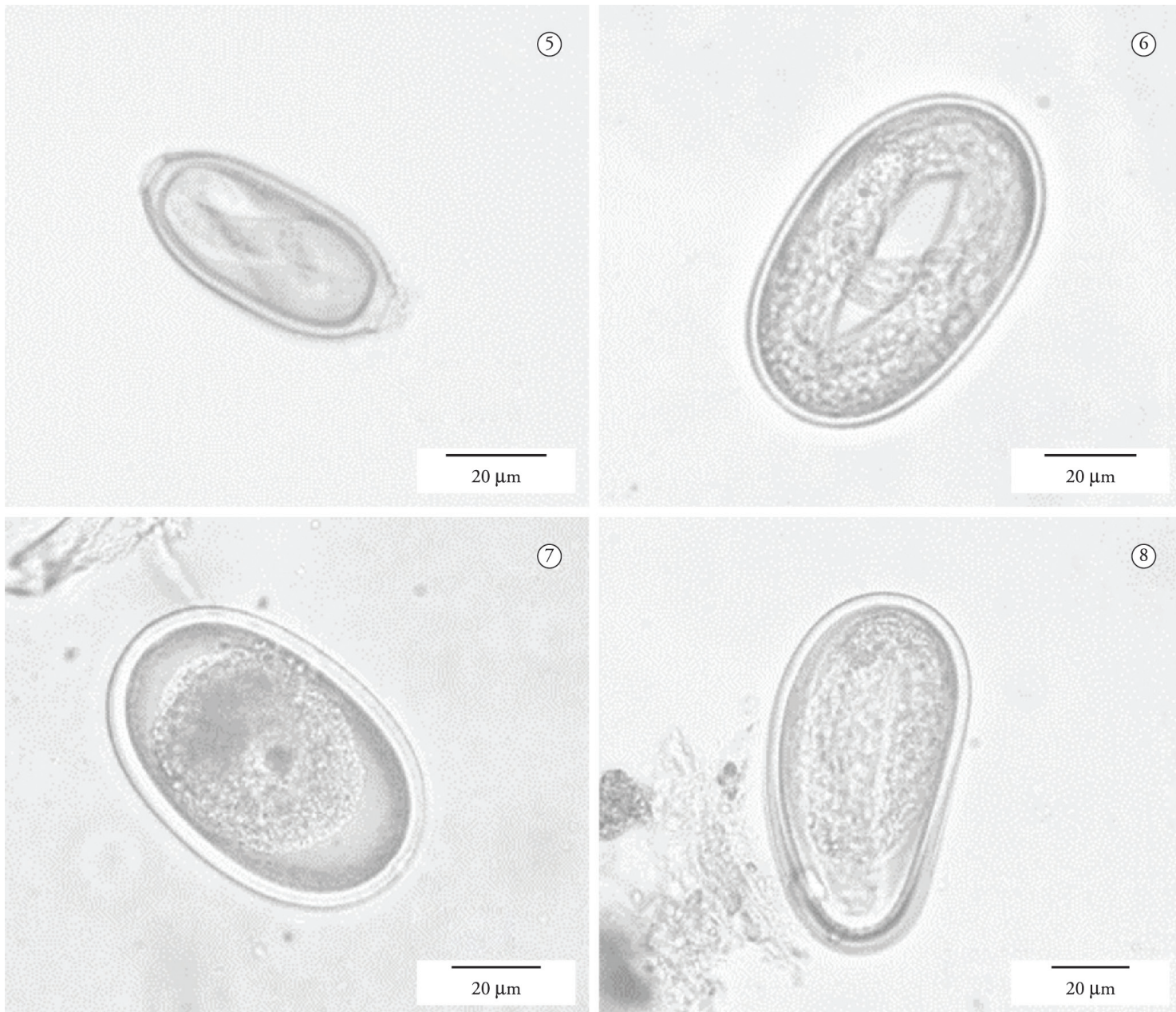

Figures 5-8. 5. Capillaria/Ornithocapillaria sp. (probably C. plagiaticia) egg; 6. Ascaridia sp. egg; 7. Heterakis sp. egg; 8. Unidentified psittacid nematode egg.

of new species, as pseudoparasites may be present in the samples (BERTO et al., 2010). The polysporocystic oocysts found in our analysis probably represents an adeleid pseudoparasite from insects.

\section{Acknowledgements}

We would like to thank the staffs from the surveyed zoos for the help with the fecal samples as well as the referees for their contributions to this manuscript. We would like to thank also Coordenação de Aperfeiçoamento de Pessoal de Nível Superior (CAPES) for research funding.

\section{References}

Allgayer MC, Guedes NMR, Chiminazzo C, Cziulik M, Weimer TA. Clinical pathology and parasitologic evaluation of free-living nestlings of the Hyacinth Macaw (Anodorhynchus hyacinthinus). J Wildl Dis 2009; 45(4): 972-981. http://dx.doi.org/10.7589/0090-3558-45.4.972. PMid:19901373
Berto BP, Lopes BB, Teixeira Filho WL, Flausino W, Lopes CWG. Coccidios de invertebrados associados ao hábito alimentar de vertebrados: uma revisão breve dos gêneros Adelea, Adelina e Barroussia. Rev Bras Med Vet 2010; 32(1): 33-41.

Clubb SL, Frenkel JK. Sarcocystis falcatula of opossums: transmission by cockroaches with fatal pulmonary disease in psittacine birds. $J$ Parasitol 1992; 78(1): 116-124. http://dx.doi.org/10.2307/3283697. PMid:1738053

Cordón GP, Prados AH, Romero D, Moreno MS, Pontes A, Osuna $A$, et al. Intestinal and haematic parasitism in the birds of the Almuñecar (Granada, Spain) ornithological garden. Vet Parasitol 2009; 165(3-4): 361-366. http://dx.doi.org/10.1016/j.vetpar.2009.07.027. PMid:19682800

Freitas JFT, Mendonça JM, Guimarães JP. Sôbre algumas espécies do gênero Capillaria Zeder, 1800 parasitas de aves (Nematoda, Trichuroidea). Mem Inst Oswaldo Cruz 1959; 57(1): 17-32. http://dx.doi. org/10.1590/S0074-02761959000100002. PMid:13814750

Freitas MFL, Oliveira JB, Cavalcanti MDB, Leite AS, Magalhães VS, Oliveira RA, et al. Parásitos gastrointestinales de aves silvestres en cautiverio en el estado de Pernambuco, Brasil. Parasitol Latinoam 2002; 57(1-2): 50-54. https://dx.doi.org/10.4067/S0717-77122002000100012. 
Gilardi KVK, Lowenstine LJ, Gilardi JD, Munn CA. A survey for selected viral, chlamydial, and parasitic diseases in wild dusky-headed parakeets (Aratinga weddellii) and tui parakeets (Brotogeris sanctithomae) in Peru.J Wildl Dis 1995; 31(4): 523-528. http://dx.doi.org/10.7589/0090-355831.4.523. PMid:8592384

Hofstatter PG, Guaraldo AMA. Eimeria abmitu n. sp. (Apicomplexa: Eimeriidae) from the razor-billed curassow Mitu tuberosum Spix (Galliformes: Cracidae). Syst Parasitol 2011a; 78(1): 69-71. http://dx.doi. org/10.1007/s11230-010-9277-4. PMid:21161492

Hofstatter PG, Guaraldo AMA. A new eimerian species (Apicomplexa: Eimeriidae) from the blue-fronted Amazon parrot Amazona aestiva L. (Aves: Psittacidae) in Brazil. J Parasitol 2011b; 97(6): 1140-1141. http:// dx.doi.org/10.1645/GE-2797.1. PMid:21612420

Masello JF, Choconi RG, Sehgal RNM, Tell L, Quillfeldt P. Blood and intestinal parasites in wild Psittaciformes: a case study of burrowing parrots (Cyanoliseus patagonus). Ornitol Neotrop 2006; 17(4): 515-529.
Patel PV, Patel AI, Sahu RK, Vyas R. Prevalence of gastro-intestinal parasites in captive birds of Gujarat Zoo's. Zoos Print J 2000; 15(7): 295-296. http://dx.doi.org/10.11609/JoTT.ZPJ.15.7.295-6.

Sheather AT. The detection of intestinal protozoa and mange parasites by a flotation technique. J Comp Pathol 1923; 36(4): 266-275. http:// dx.doi.org/10.1016/S0368-1742(23)80052-2.

Stone EG, Montiel-Parra G, Pérez TM. A survey of selected parasitic and viral pathogens in four species of Mexican parrots, Amazona autumnalis, Amazona oratrix, Amazona viridigenalis, and Rhynchopsitta pachyrhyncha. J Zoo Wildl Med 2005; 36(2): 245-249. http://dx.doi.org/10.1638/04026.1. PMid:17323565

Upton SJ, Ernst JV, Clubb SL, Current WL. Eimeria forresteri n. sp. (Apicomplexa: Eimeriidae) from Ramphastos toco and a redescription of Isospora graculai from Gracula religiosa. Syst Parasitol 1984; 6(3): 237-240. http://dx.doi.org/10.1007/BF00009233. 